FOLIA POMERANAE UNIVERSITATIS TECHNOLOGIAE STETINENSIS

Folia Pomer. Univ. Technol. Stetin., Oeconomica 2017, 337(88)3, 67-76

Mateusz TOMAL

\title{
IDENTYFIKACJA CZYNNIKÓW WPŁYWAJACYCH NA PODEJMOWANIE DEWELOPERSKICH INWESTYCJI MIESZKANIOWYCH W GMINACH WOJEWÓDZTWA MAŁOPOLSKIEGO
}

\section{IDENTIFYING THE FACTORS THAT SIGNIFICANTLY INFLUENCE DECISIONS TO MAKE HOUSING DEVELOPMENT INVESTMENTS IN THE COMMUNES OF MAŁOPOLSKA PROVINCE}

Katedra Ekonomiki Nieruchomości i Procesu Inwestycyjnego, Uniwersytet Ekonomiczny w Krakowie ul. Rakowicka 27, 31-510 Kraków, e-mail: mateusz.tomal@gmail.com

\begin{abstract}
Summary. The aim of this article was to identify the factors that significantly influence decisions to make housing development investments in the communes of Małopolska Province. Subject to verification were variables that characterize the socioeconomic aspects of the region and the saturation level of the local residential market. The period of study included the latest available data and covered the years 2013-2015. The analysis conducted with the use of a multiple regression model showed that developers took three factors into consideration while taking decisions related to the location of a new residential project. The significant aspects were the number of people inhabiting a given commune, the number of entities entered in the National Official Business Register per 10.000 people, and the share of registered unemployed persons in the working-age population. What is more, the significant factors were given weights informing us about the extent to which they influence the explained variable. The obtained results indicated that entrepreneurs in the primary market ascribed the most important role to the number of people inhabiting a given area.
\end{abstract}

Słowa kluczowe: inwestycje mieszkaniowe, modele ekonometryczne, rynek mieszkaniowy, województwo małopolskie.

Key words: econometric models, housing investments, housing market, małopolska province.

\section{WSTĘP}

Jedną z podstawowych potrzeb każdego człowieka jest zaspokojenie wymogów mieszkaniowych. Zrealizowanie tej potrzeby może odbyć się poprzez budowę, zakup lub wynajem odpowiedniej nieruchomości. Należy zauważyć, że inwestycja mieszkaniowa dla pojedynczej osoby czy rodziny może być procesem niezwykle skomplikowanym, który nie musi skończyć się pozytywnym efektem. W związku z tym na rynku nieruchomości mieszkaniowych aktywnie działa wiele przedsiębiorstw zwanych deweloperami, których celem jest dostarczenie lokalnej ludności właściwej liczby lokalów czy domów mieszkalnych.

Kluczowym etapem każdego projektu deweloperskiego na rynku nieruchomości mieszkaniowych jest wybór odpowiedniej lokalizacji (Li i in. 2005). Należy nadmienić, że deweloper, uwzględniając ryzyko prowadzonej działalności, liczy na osiągnięcie zakładanego poziomu zysku (Gostkowska-Drzewicka 2007). Podjęcie złej decyzji w zakresie ulokowania inwestycji skazuje przedsiębiorcę 
na straty, a niekiedy prowadzi do zachwiania kondycji całej firmy. Na ustalenie dogodnej lokalizacji przyszłej inwestycji mają wpływ nie tylko czynniki odnoszące się bezpośrednio do danej nieruchomości, takie jak: uzbrojenie terenu, kształt czy poziom nachylenia. Racjonalnie działający deweloper w procesie podejmowania decyzji odnoście do lokalizacji nieruchomości mieszkaniowej powinien uwzględnić także inne okoliczności, które dotyczą sytuacji ekonomicznej danego regionu oraz stanu rynku nieruchomości, w szczególności jego nasycenia (Kokot 2012).

Celem niniejszego artykułu jest wykrycie czynników, które istotnie wpływają na decyzje dotyczące lokalizacji przyszłych inwestycji mieszkaniowych na rynku pierwotnym w gminach województwa małopolskiego. Punktem wyjścia przeprowadzonej analizy było zebranie danych dotyczących liczby mieszkań oddanych do użytkowania przez deweloperów w latach 2014-2015 oraz uwarunkowań mogących istotnie wpływać na decyzje podejmowane przez przedsiębiorców w zakresie inwestycji mieszkaniowych. Identyfikacja istotnych czynników wpływających na aktywność deweloperów w danej gminie została przeprowadzona za pomocą regresji wielorakiej.

\section{UWARUNKOWANIA WYBORU LOKALIZACJI DEWELOPERSKIEJ INWESTYCJI MIESZKANIOWEJ}

Analizując literaturę przedmiotu, można stwierdzić, że deweloper jest przedsiębiorcą, który działa głównie na rynku nieruchomości mieszkaniowych (Trojanowski 2004). Wykonując swoją działalność, deweloper identyfikuje fragment rynku mieszkaniowego, na którym istnieje popyt, a następnie organizuje inwestycję, której wynikiem jest dostarczenie na rynek nowych mieszkań (Kirejczyk i Łaszek 1997). Nowe obiekty budowlane zazwyczaj przeznaczone są na sprzedaż lub wynajem (Bryx i Matkowski 2001). Należy jednak zauważyć, że na polskim rynku nieruchomości dominują przedsięwzięcia, których finalnym celem jest sprzedaż nieruchomości. W literaturze można także spotkać wiele innych definicji dewelopera. Miles i in. (2007) osobę dewelopera porównują do producenta filmowego odpowiedzialnego za wybór środków i ludzi w celu zrealizowania danego projektu.

Przeprowadzenie udanej inwestycji na rynku pierwotnym jest zadaniem niezwykle skomplikowanym oraz długotrwałym. Na etapy tego procesu składają się następujące działania (Kucharska-Stasiak 2006):

- wybór nieruchomości,

- analiza ekonomiczna inwestycji,

- zakup praw do nieruchomości,

- wykonanie dokumentacji projektowej,

- uzyskanie pozwoleń oraz finansowania,

- realizacja obiektów budowlanych,

- sprzedaż lub wynajem nieruchomości.

Wieloetapowość inwestycji deweloperskiej zmusza przedsiębiorcę prowadzącego tego typu działalność do podejmowania w pełni przemyślanych oraz racjonalnych decyzji. Z każdym etapem procesu inwestycyjnego wiąże się możliwość pojawienia się pewnych nieprawidłowości, które mogą narazić na niepowodzenie całe przedsięwzięcie deweloperskie. Należy także zwrócić uwagę na to, że tego typu projekty narażone są nie tylko na negatywne czynniki 
związane z samym procesem inwestycyjnym, ale także na wpływy makroekonomiczne. Zła kondycja gospodarki może doprowadzić do upadku nie tylko projektów, ale całych przedsiębiorstw deweloperskich, co miało miejsce podczas ostatniego ogólnoświatowego kryzysu finansowego. Deweloperzy, bazując na danych z lat 2006-2007, zauważyli, że na rynku nieruchomości mieszkaniowych występuje znaczny deficyt mieszkań, co mogło wynikać z popytu spekulacyjnego (Gostkowska-Drzewicka 2012). W związku z czym przystąpili do realizacji projektów mieszkaniowych. Jednak nowa podaż została zauważona na rynku dopiero w latach 2008-2009, co wynika z długości inwestycji mieszkaniowej. Wzrost podaży na rynku zbiegł się z wystąpieniem kryzysu finansowego, co doprowadziło do znacznego spadku cen nieruchomości i drastycznego osłabienia sektora deweloperskiego. Należy więc stwierdzić, że deweloper, uruchamiając inwestycję, powinien dążyć do minimalizacji wystąpienia wszelkich negatywnych efektów mogących wpłynąć na powodzenie całego projektu.

Jednym z pierwszych działań podejmowanych przez dewelopera jest wybór odpowiedniej lokalizacji przyszłego przedsięwzięcia. Można to rozumieć jako decyzję w zakresie nie konkretnej nieruchomości, a w znaczeniu szerszym, odnoszącym się do danego regionu, który może pokrywać się z granicami administracyjnymi miasta czy gminy. Wagę czynnika, jakim jest lokalizacja, należy szczególnie podkreślić, ponieważ razem z pomysłem i kapitałem tworzą istotę inwestycji deweloperskiej (Dąbrowski i Kirejczyk 2001). Racjonalnie działający deweloper, dokonując wyboru odpowiedniej lokalizacji, poprzez analizę dostępnych informacji może zminimalizować negatywne efekty mogące doprowadzić do braku popytu na nowe mieszkania. Kokot (2010) uwarunkowania dotyczące wyboru inwestycji deweloperskiej dzieli na dwie grupy - charakteryzujące stan społeczno-ekonomiczny danego regionu oraz stan rynku nieruchomości na badanym obszarze. Do zmiennych społeczno-ekonomicznych można przykładowo zaliczyć: liczbę mieszkańców, stopę bezrobocia oraz przeciętne wynagrodzenie brutto. Stan rynku nieruchomości, w szczególności poziom jego nasycenia, można przedstawić za pomocą zmiennej informującej o liczbie mieszkań na 1000 mieszkańców. Należy zauważyć, że wśród wymienionych zmiennych charakter stymulant mają jedynie liczba mieszkańców oraz przeciętne wynagrodzenie brutto. Inne wymienione wskaźniki należy scharakteryzować jako destymulanty. Bazując na wyżej wymienionych wskaźnikach najlepszym obszarem przyszłej inwestycji są regiony o wysokim poziomie społeczno-ekonomicznym oraz niskim nasyceniu rynku. Wydaje się jednak, że - pomimo powszechnie dostępnych informacji - deweloperzy nie zachowują się w pełni racjonalnie, ignorując w szczególności dane o nasyceniu lokalnego rynku nieruchomości.

\section{METODA}

W celu wykrycia czynników, które wpływają na wybór ogólnej lokalizacji przyszłej inwestycji deweloperskiej, posłużono się modelem ekonometrycznym postaci:

$$
Y=\alpha_{0}+\alpha_{1} X_{1}+\cdots+\alpha_{K} X_{K}+\varepsilon
$$

gdzie:

$Y$ - zmienna objaśniana,

$X_{1}, \ldots, X_{K}$ - zmienne objaśniające,

$K$ - liczba zmiennych, 
$\alpha_{0}, \ldots, \alpha_{K}-$ parametry strukturalne modelu; po estymacji modelu otrzymuje się oceny parametrów strukturalnych: $a_{0}, \ldots, a_{K}$,

$\varepsilon-$ czynnik losowy.

$\mathrm{Na}$ podstawie analizy literatury oraz dostępności danych przyjęto 9 zmiennych objaśniających charakteryzujących poszczególne gminy województwa małopolskiego w roku 2013. Za ocenę poziomu nasycenia rynku przyjęto liczbę mieszkań przypadającą na 1000 mieszkańców $-X_{1}$. W zakresie czynników społeczno-gospodarczych pozyskano takie dane, jak: $X_{2}$-odsetek ludności korzystającej z wodociągu, $X_{3}$ - odsetek ludności korzystającej z kanalizacji, $X_{4}$ - odsetek ludności korzystającej z gazu, $X_{5}$ - liczba podmiotów wpisanych do rejestru REGON na 10 tys. osób, $X_{6}-$ udział bezrobotnych zarejestrowanych w liczbie ludności w wieku produkcyjnym, $X_{7}$ - dochody własne gminy na 1 mieszkańca, $X_{8}-$ liczba ludności w gminie. Ponadto dodano zmienną binarną dotyczącą położenia gminy w krakowskim obszarze metropolitalnym - $X_{9}$, aby uwzględnić oddziaływanie stolicy województwa. W ocenie atrakcyjności danych regionów jako lokalizacji nowych inwestycji deweloperskich charakter destymulanty mają dwie zmienne - udział bezrobotnych zarejestrowanych w liczbie ludności w wieku produkcyjnym oraz liczba mieszkań przypadająca na 1000 mieszkańców.

W celu uzyskania jednolitego charakteru danych zmienne te przekształcono w stymulanty, które zostały oznaczone kolejno jako $X_{6}^{\prime}$ oraz $X_{1}^{\prime}$. W tym celu wykorzystano wzór (Łogwiniuk 2011):

$$
x_{i j}^{\prime}=\frac{1}{x_{i j}}
$$

gdzie:

$$
x_{i j}-i \text {-ta wartość } j \text {-tej zmiennej }(i=1,2, \ldots, n),
$$

$x_{i j}^{\prime}$ - przekształcona $i$-ta wartość $j$-tej zmiennej.

Przy założeniu, że typowa inwestycja na rynku pierwotnym trwa około 12-24 miesięcy, zmienną objaśnianą została cecha opisująca liczbę mieszkań oddanych do użytkowania przez deweloperów w roku 2014 oraz w roku 2015 na 10 tys. mieszkańców ( $Y$ ). Dane z roku 2016 na dzień pozyskania informacji (1.03.2017) nie były jeszcze dostępne.

Po estymacji modelu ekonometrycznego sprawdzono istotność ocen parametrów strukturalnych za pomocą testu t-Studenta, który przyjmuje następujące hipotezy:

$$
\begin{aligned}
& H_{0}: \alpha_{j}=0, \\
& H_{1}: \alpha_{j} \neq 0 .
\end{aligned}
$$

Statystyka testu określona jest wzorem:

$$
t\left(a_{j}\right)=\frac{a_{j}}{D\left(a_{j}\right)}
$$

gdzie:

$a_{j}$ - ocena $j$-tego parametru $(j=0, \ldots, K)$,

$D\left(a_{j}\right)$ - średni błąd szacunku j-tego parametru.

Hipoteza zerowa podlega odrzuceniu w przypadku, gdy $\left|t\left(a_{j}\right)\right|>t_{\alpha}$, gdzie wartość krytyczną $t_{\alpha}$ odczytuje się z tablic rozkładu t-Studenta dla $n-(K+1)$ stopni swobody, przy założeniu danego poziomu istotności $\alpha$.W przypadku tej analizy przyjęto $\alpha=0,1$. Zmienne eliminowano w postępowaniu krokowym, odrzucając jedną zmienną nieistotną, a następnie ponownie wyznaczono oceny parametrów strukturalnych oraz sprawdzono ich istotność. 
Ponadto w celu weryfikacji poprawności otrzymanego modelu wyznaczono współczynnik determinacji $R^{2}$, który informuje, w jakim stopniu zmienność zmiennej objaśnianej została wyjaśniona przez model. Wyrażany jest on wzorem:

$$
R^{2}=\frac{\sum_{i=1}^{n}\left(\hat{y}_{i}-\bar{y}\right)^{2}}{\sum_{i=1}^{n}\left(y_{i}-\bar{y}\right)^{2}}
$$

gdzie:

$\hat{y}_{i}-i$-ta wartość przewidywana zmiennej zależnej,

$y_{i}-i$-ta wartość rzeczywista zmiennej objaśnianej,

$\bar{y}$ - średnia arytmetyczna wartości rzeczywistych.

Po wyznaczeniu czynników, które istotnie wpływały na decyzje w zakresie lokalizacji inwestycji deweloperskich w gminach województwa małopolskiego, poszczególnym zmiennym przyporządkowano wagi, aby określić, która zmienna miała największy wpływ na aktywność inwestycyjną na rynku pierwotnym. W tym celu istotne oceny parametrów strukturalnych poddano standaryzacji z powodu różnych skali ich wielkości. Procedurę tą przeprowadzono za pomocą wzoru:

$$
a_{j}^{*}=\frac{a_{j} \cdot s\left(X_{j}\right)}{s(Y)}
$$

gdzie:

$a_{j}^{*}$ - standaryzowany $j$-ty parametr modelu,

$s\left(X_{j}\right)$ - odchylenie standardowe j-tej zmiennej objaśniającej,

$s(Y)$ - odchylenie standardowe zmiennej objaśnianej.

W celu wyznaczenia wag poszczególnych zmiennych, mówiących o sile oddziaływania na zmienną objaśnianą, posłużono się wzorem (Nalepka i Tomal 2016):

$$
w_{j}^{*}=\frac{\left|a_{j}^{*}\right|}{\sum_{j=1}^{K}\left|a_{j}^{*}\right|}
$$

gdzie:

$$
w_{j}^{*} \text { - waga } j \text {-tej zmiennej objaśniającej. }
$$

Zaproponowana ocena poszczególnych czynników poprzez przypisanie im poszczególnych wag umożliwia łatwy oraz czytelny sposób interpretacji uzyskanych wyników. Wagi mogą być stosowane także w wielu innych sytuacjach na rynku nieruchomości, w szczególności podczas określenia siły wpływu poszczególnych cech na ceny nieruchomości.

\section{WYNIKI}

W latach 2014-2015 deweloperzy w województwie małopolskim dostarczyli na sprzedaż lub wynajem ok. 13 tysięcy mieszkań. Zdecydowana większość, bo aż ok. 11,5 tysiąca została wybudowana w stolicy województwa - w Krakowie. Jeżeli weźmie się pod uwagę liczbę nowych mieszkań na 10 tys. osób, ponownie miasto Kraków osiągnie największą wartość, czyli 155 mieszkań. Druga z kolei jest gmina Zielonki, gdzie na rynku pierwotnym pojawiło się 68 lokali na 10 tys. osób. Tuż za nią plasuje się gmina Wieliczka z liczbą 67 nowych nieruchomości mieszkalnych. Należy zauważyć, że gmina Zielonki oraz Wieliczka znajdują się w bezpośrednim sąsiedztwie Krakowa, co przyczynia się do ich szybkiego rozwoju społeczno-ekonomicznego. Na kolejnym miejscu z wynikiem 47 mieszkań znajduje się gmina Zakopane, co może wynikać z jej turystycznego charakteru. 
Uwzględniając zmienne oraz procedurę opisaną w poprzednim rozdziale artykułu, oszacowano wstępny jednorównaniowy model ekonometryczny wyjaśniający aktywność deweloperów w gminach województwa małopolskiego. Wyniki estymacji zawiera tab. 1.

Tabela 1. Model objaśniający aktywność deweloperów

\begin{tabular}{|l|r|r|r|r|c|}
\hline$n=182, R^{2}=0,7$ & \multicolumn{1}{|c|}{$a_{j}$} & $D\left(a_{j}\right)$ & $t\left(a_{j}\right)$ & $\mathrm{p}$-value & Istotność \\
\hline Stała & $-16,77144$ & 8,70559 & $-1,92651$ & 0,05569 & tak \\
\hline$X_{1}^{\prime}$ & 232,09668 & 1778,61500 & 0,13049 & 0,89633 & nie \\
\hline$X_{2}$ & $-0,01377$ & 0,02675 & $-0,51492$ & 0,60727 & nie \\
\hline$X_{3}$ & 0,00161 & 0,03390 & 0,04739 & 0,96225 & nie \\
\hline$X_{4}$ & 0,00788 & 0,02224 & 0,35448 & 0,72341 & nie \\
\hline$X_{5}$ & 0,01489 & 0,00370 & 4,01914 & 0,00009 & tak \\
\hline$X_{6}^{\prime}$ & 36,14348 & 20,48592 & 1,76431 & 0,07946 & tak \\
\hline$X_{7}$ & 0,00018 & 0,00224 & 0,08036 & 0,93605 & nie \\
\hline$X_{8}$ & 0,00018 & 0,00001 & 14,50110 & 0,00000 & tak \\
\hline$X_{9}$ & 2,34475 & 1,69576 & 1,38272 & 0,16854 & nie \\
\hline
\end{tabular}

Źródło: opracowano na podstawie indywidualnych danych nieidentyfikowalnych udostępnionych przez GUS.

$\mathrm{Na}$ podstawie wyników estymacji modelu przedstawionych w powyższej tabeli należy stwierdzić, że tylko trzy czynniki okazały się istotne: liczba podmiotów wpisanych do rejestru REGON na 10 tys. osób, udział zarejestrowanych bezrobotnych w liczbie ludności w wieku produkcyjnym oraz liczba ludności w gminie. Następnie po krokowej eliminacji zmiennych nieistotnych oszacowano końcowy model ekonometryczny. Wyniki badania przedstawia tab. 2 . Należy zauważyć, że podane wartości ocen parametrów oraz ich błędów w tab. 1 oraz tab. 2 mają charakter przybliżony. Przedstawione statystyki t-Studenta zostały obliczone na podstawie wyników o większej dokładności.

Tabela 2. Model objaśniający aktywność deweloperów po eliminacji zmiennych nieistotnych

\begin{tabular}{|l|c|c|c|c|c|}
\hline \multicolumn{1}{|c|}{$n=182$} & $a_{j}$ & $D\left(a_{j}\right)$ & $t\left(a_{j}\right)$ & $\mathrm{p}$-value & Istotność \\
\hline Stała & $-17,46525$ & 2,60385 & $-6,70746$ & 0,000000 & tak \\
\hline$X_{5}$ & 0,01511 & 0,00250 & 6,04653 & 0,000000 & tak \\
\hline$X_{6}^{\prime}$ & 50,37098 & 16,87068 & 2,98571 & 0,003228 & tak \\
\hline$X_{8}$ & 0,00018 & 0,00001 & 15,45567 & 0,000000 & tak \\
\hline
\end{tabular}

Źródło: opracowano na podstawie indywidualnych danych nieidentyfikowalnych udostępnionych przez GUS.

Po eliminacji zmiennych nieistotnych w finalnym modelu wartość współczynnika determinacji $R^{2}$ wyniosła 0,7, co świadczy o dobrym stopniu wyjaśnienia zmienności zmiennej zależnej. Analizując znaki oszacowanych ocen parametrów strukturalnych, należy stwierdzić, że wszystkie istotne cechy pozytywnie wpływały na aktywność deweloperów w gminach województwa małopolskiego. W szczególności większa liczba ludności oraz podmiotów wpisanych do rejestru REGON na 10 tys. mieszkańców oraz mniejszy udział zarejestrowanych bezrobotnych 
w liczbie ludności w wieku produkcyjnym wpływają na wzrost liczby mieszkań oddanych do użytkowania na 10 tys. osób. Należy pamiętać, że zmienna odnosząca się do udziału bezrobotnych została przekształcona w stymulantę, wobec czego dodatni parametr należy interpretować jako zjawisko korzystne. W przypadku niedokonania tego typu przekształcenia pożądany byłby parametr ujemny.

Uzyskane wyniki estymacji potwierdziły przypuszczenie, że deweloperzy działający na rynku w niedostateczny sposób analizują lokalny rynek nieruchomości. Poziom nasycenia danego regionu lokalami mieszkalnymi wydaje się bardzo ważnym elementem z punktu widzenia późniejszego popytu na oferowane nieruchomości. W przypadku wystąpienia kryzysu gospodarczego oraz przesycenia rynku mieszkaniowego ceny nowych mieszkań mogą ulec drastycznej obniżce, co może doprowadzić do bankructwa przedsiębiorstwa.

Następnym etapem badania było znalezienie odpowiedzi na pytanie, który czynnik ma największą siłę oddziaływania na wybór lokalizacji przyszłej inwestycji deweloperskiej. W tym celu oszacowano standaryzowane parametry modelu oraz wagi zmiennych. Wyniki analizy przedstawia tab. 3.

Tabela 3. Standaryzowane parametry modelu oraz wagi zmiennych

\begin{tabular}{|l|c|c|c|}
\hline \multicolumn{1}{|c|}{ Zmienne } & $\left|a_{j}^{*}\right|$ & $w_{j}^{*}$ & $w_{j}^{*}[\%]$ \\
\hline$X_{5}$ & 0,27 & 0,25 & 25 \\
\hline$X_{6}^{\prime}$ & 0,13 & 0,12 & 12 \\
\hline$X_{8}$ & 0,67 & 0,63 & 63 \\
\hline Suma & 1,07 & 1,00 & 100 \\
\hline
\end{tabular}

Źródło: opracowano na podstawie tab. 2.
Otrzymane wagi wskazują, że deweloperzy, planując przyszłą inwestycję, największą rolę przypisują liczbie ludności na danym obszarze. Waga tej zmiennej wynosi aż $63 \%$. Wydaje się, że tego typu podejście jest racjonalne. Jednak nawet największe lokalne rynki mieszkaniowe mogą dojść do punktu krytycznego, w którym

nasycenie obiektami będzie tak duże, że dostarczone na rynek nowe nieruchomości nie znajdą właścicieli. Kolejnym czynnikiem wpływającym na aktywność przedsięwzięć deweloperskich z wagą 25\% jest liczba podmiotów gospodarczych wpisanych do rejestru REGON na 10 tys. osób. Cecha ta odnosi się bezpośrednio do stanu gospodarczego danego regionu. Im więcej przedsiębiorstw jest na danym terenie, tym więcej jest osób mogących pozwolić sobie na zakup mieszkania. Duża liczba przedsiębiorstw tworzy także aurę dobrze prosperującej gminy, która przyciąga nowych mieszkańców, a w konsekwencji deweloperów. Ostatnim czynnikiem, który okazał się istotny $w$ badaniu, jest udział zarejestrowanych bezrobotnych $w$ liczbie ludności w wieku produkcyjnym. Waga tej cechy okazała się najmniejsza - wyniosła $12 \%$. W przypadku projektów deweloperskich dobra, jakie są dostarczane na rynek, cechują się dużą kapitałochłonnością. Posiadanie stabilnego zatrudnienia wiąże się z otrzymywaniem regularnych dochodów, co zwiększa możliwość zakupu lub wynajmu nieruchomości od dewelopera. Lokalizując inwestycję deweloperską w regionie o niskiej stopie bezrobocia, przedsiębiorca w dużym stopniu niweluje ryzyko wiążące się z brakiem potencjalnych nabywców na oferowane przez niego nieruchomości. 


\section{PODSUMOWANIE}

Deweloper, planując inwestycję, musi wybrać odpowiednią lokalizację, która zminimalizuje ryzyko niepowodzenia przyszłego przedsięwzięcia. Należy przez to rozumieć nie tylko dobór konkretnej nieruchomości, ale także wybór regionu, który może być utożsamiany z gminą, powiatem czy nawet województwem.

Przedsiębiorca, analizując potencjalne miejsca inwestycji, powinien wziąć pod uwagę czynniki społeczno-ekonomiczne danego regionu oraz nasycenie lokalnego rynku nieruchomości mieszkaniowych. Tego typu działanie znacznie zwiększy szanse dewelopera na sprzedaż lub wynajem dostarczanych na rynek lokali czy domów mieszkalnych. Należy ponadto zauważyć, że deweloper narażony jest na bardzo negatywne efekty wynikające z załamań gospodarczych, dlatego racjonalna analiza dotycząca lokalizacji przyszłej inwestycji jest niezwykle ważna i pożądana.

Wyniki badań zaprezentowanych w niniejszym artykule wskazują, że w analizowanym okresie na wybór danej gminy województwa małopolskiego jako miejsca przedsięwzięcia deweloperskiego wpływają trzy czynniki: liczba podmiotów wpisanych do rejestru REGON na 10 tys. osób, udział zarejestrowanych bezrobotnych w liczbie ludności w wieku produkcyjnym oraz liczba ludności w gminie. Wszystkie istotne zmienne pozytywnie wpływają na aktywność deweloperów, co oznacza, że wzrost liczby podmiotów w rejestrze REGON, wzrost liczby ludności w gminie oraz spadek udziału bezrobotnych wpływają na wzrost liczby oddawanych do użytkowania mieszkań przez deweloperów. Należy zauważyć, że największy wpływ wśród istotnych cech ma zmienna dostarczająca informacji o liczbie ludności w gminie, która ma wagę na poziomie 63\%. Druga pod względem siły wpływu jest cecha opisująca liczbę podmiotów w rejestrze REGON z wagą 25\%. Najmniej na zmienną objaśnianą oddziałuje cecha dotycząca udziału bezrobotnych, której waga wynosi $12 \%$.

Dodatkowo analiza wykazała, że deweloperzy - pomimo zwracania uwagi na aspekty społeczno-gospodarcze danego regionu - przy podejmowania decyzji dotyczącej wyboru ogólnej lokalizacji przyszłej inwestycji nie przywiązują wagi do stanu lokalnego rynku nieruchomości w zakresie jego nasycenia nieruchomościami mieszkaniowymi. Pominięcie tego faktu naraża przedsiębiorcę na ryzyko związane z brakiem popytu na oferowane przez niego nieruchomości.

Zdecydowanie najlepszym rozwiązaniem minimalizującym ryzyko inwestycji deweloperskiej jest wybór lokalizacji cechującej się dobrymi cechami społeczno-gospodarczymi oraz stosunkowo małym nasyceniem lokalnego rynku nieruchomości.

\section{PIŚMIENNICTWO}

Bryx M., Matkowski R. 2001. Inwestycje w nieruchomości. Warszawa, POLTEX, 126.

Dąbrowski M., Kirejczyk K. 2001. Inwestycje deweloperskie. Warszawa, Twigger, 14.

Gostkowska-Drzewicka M. 2007. Istota działalności deweloperskiej w literaturze przedmiotu. Probl. Rozw. Miast 4, 112.

Gostkowska-Drzewicka M. 2012. Model funkcjonowania rynku deweloperskiego. Zarządz. Finan. 2(1), 52.

Kirejczyk K., Łaszek J. 1997. Vademecum dewelopera. Kraków, KIN, 18.

Kokot S. 2010. Uwarunkowania podejmowania inwestycji deweloperskich w głównych miastach Polski. Wiad. Stat. 6, 38. 
Kokot S. 2012. Analiza zmian uwarunkowań podejmowania inwestycji deweloperskich w wybranych miastach Polski. Stud. Mater. TNN 20(1), 56.

Kucharska-Stasiak E. 2006. Nieruchomość w gospodarce rynkowej. Warszawa, PWN, 231.

Li H., Yu L., Cheng E.W.L. 2005. A GIS-Based site selection system for real estate projects. Constr. Innov. 5(4), 231.

Łogwiniuk K. 2011. Zastosowanie metod taksonomicznych w analizie porównawczej dostępu do infrastruktury ICT przez młodzież szkolną w Polsce. Ekon. Zarządz. 1, 11.

Miles M.E., Berens G.L., Eppli M.J., Weiss M.A. 2007. Real estate development: Principles and process. Washington, ULI, 8.

Nalepka A., Tomal M. 2016. Identyfikacja czynników kształtujących ceny ofertowe deweloperskich lokali mieszkalnych na obszarze jednostki ewidencyjnej Nowa Huta. Świat Nieruch. 2(96), 16.

Trojanowski D. 2004. Miejsce dewelopera na rynku nieruchomości. Zesz. Nauk. UGdań. 1, 212.

Streszczenie. Celem artykułu jest identyfikacja czynników istotnie wpływających na podejmowanie deweloperskich inwestycji mieszkaniowych w gminach województwa małopolskiego. Weryfikacji poddano zmienne charakteryzujące aspekty społeczno-gospodarcze danego regionu oraz poziom nasycenia lokalnego rynku mieszkaniowego. Okres badania uwzględnia najnowsze dostępne dane i obejmuje lata 2013-2015. Przeprowadzona analiza za pomocą modelu regresji wielorakiej wykazała, że deweloperzy kierują się trzema istotnymi czynnikami podczas podejmowania decyzji odnośnie do lokalizacji inwestycji mieszkaniowej; są to: liczba ludności w gminie, liczba podmiotów w rejestrze REGON na 10 tys. mieszkańców oraz udział bezrobotnych zarejestrowanych w liczbie ludności w wieku produkcyjnym. Istotnym czynnikom przypisano wagi informujące o sile wpływu danej cechy na zmienną objaśnianą. Uzyskane wyniki wskazały, że przedsiębiorcy na rynku pierwotnym największą rolę przypisują liczbie ludności na danym obszarze.

Publikacja została sfinansowana ze środków MNiSW przyznanych Wydziałowi Ekonomii i Stosunków Międzynarodowych Uniwersytetu Ekonomicznego w Krakowie na badania młodych naukowców oraz uczestników studiów doktoranckich. 
